\title{
GAMBARAN STATUS GIZI IBU HAMIL YANG MELAHIRKAN BAYI DENGAN BBLR PUSKESMAS CIGALONTANG KABUPATEN TASIKMALAYA TAHUN 2014
}

Oleh :

\section{H. Aam Nursalam, S.KM,M.Mkes}

\section{A. Abstrak}

Dari data yang diperoleh dari Wilayah Kerja Puskesmas Cigalontang ada 148 ibu bersalin dan ada 51 ibu yang melahirkan bayi yang berat badannya <2500 gram, Faktor penyebab masalah kurang gizi yang menimpa ibu saat hamil merupakan faktor yang berperan atas tingginya kejadian BBLR. Masa kehamilan merupakan periode yang sangat penting bagi pembentukan kualitas sumber daya manusia dimasa yang akan datang, karena tumbuh kembang anak akan sangat ditentukan oleh kondisi pada saat janin dalam kandungan. Tujuan dari penelitian adalah mengetahui Gambaran status gizi ibu hamil yang melahirkan bayi dengan BBLR Puskesmas Cigalontang Kabupaten Tasikmalaya tahun 2014.

Jenis Penelitian yang digunakan adalah kuantitatif dengan metode deskriptif. Populasi untuk kelompok kasus pada penelitian ini adalah Bayi yang berat badannya rendah (BBLR) dan memiliki data lengkap dalam buku register yaitu sejumlah 76 bayi. Tehnik pengambilan sampel adalah total sampling. Instrumen dalam penelitian adalah buku register Puskesmas Cigalontang. Analisis data yang digunakan adalah univariat.

Hasil penelitian didapatkan bahwa mayoritas ibu hamil yang memiliki bayi BBLR adalah gizi kurang $(89,4 \%)$.

Simpulan dari penelitian didapatkan bahwa mayoritas ibu hamil yang memiliki bayi BBLR adalah gizi kurang (89,4\%).Rekomendasi saran adalah untuk calon ibu hamil persiapan menghadapi kehamilan salah satunya adalah status gizi pada ibu. Dimana gizi ibu akan menentukan keadan gizi bayinya. Ibu hamil memerlukan nutrisi yang cukup dalam menjaga kebutuhan ibu dan janinnya. Bagi ibu hamil dengan gizi kurang memerlukan upaya pemantauan status gizi secara berkala serta mendapatkan bantuan $P M T$ (pemberian makanan tambahan)

\section{Kata Kunci : Status gizi ibu hamil, BBLR}




\section{B. Latar belakang}

Bayi lahir dengan berat badan lahir rendah merupakan salah satu faktor resiko yang mempunyai kontribusi terhadap kematian bayi khususunya pada masa perinatal. Bayi BBLR dapat mengalami ganguan mental dan fisik pada usia tumbuh kembang selanjutnya sehingga membutuhkan biaya perawatan yang tinggi. Berat bayi lahir merupakan cerminan dari status kesehatan dan gizi selama hamil serta pelayanan antenatal care yang diterima ibu. Gizi ibu yang buruk sebelum kehamilan maupun sedang hamil lebih sering menghasilkan bayi BBLR atau lahir mati dan bisa menyebabkan cacat bawaan (Kusumawati, 2007).

Menurut WHO tahun 1990 sekitar 25 juta BBLR lahir diseluruh dunia, 90\% terjadi di negara berkembang. Bayi Berat Lahir Rendah (BBLR) merupakan penyebab utama kematian neonatal di indonesia, yaitu sebanyak 29\%. Insidensi BBLR di Rumah Sakit di Indonesia berkisar 20\%. Di pusat rujukan regional Jawa Barat setiap tahunnya antara $20-25 \%$ kelahiran BBLR, sedangkan di daerah pedesaan / rural 10,5\%. Di daerah pedesaan sebagian besar BBLR meninggal dalam masa neonatal. Sementara di level II di tingkat kabupaten di Jawa Barat sebagian besar Bayi Berat Lahir Sangat Rendah (BBLSR).

Dari data yang diperoleh dari Wilayah Kerja Puskesmas Cigalontang ada 148 ibu bersalin dan ada 51 ibu yang melahirkan bayi yang berat badannya $<2500$ gram, Faktor penyebab masalah kurang gizi yang menimpa ibu saat hamil merupakan faktor yang berperan atas tingginya kejadian BBLR .

Masa kehamilan merupakan periode yang sangat penting bagi pembentukan kualitas sumber daya manusia dimasa yang akan datang, karena tumbuh kembang anak akan sangat ditentukan oleh kondisi pada saat janin dalam kandungan. Selanjutnya berat lahir yang normal menjadi titik awal yang baik bagi proses tumbuh kembang pasca lahir, serta menjadi petunjuk bagi kualitas hidup selanjutnya, karena berat lahir yang normal dapat menurunkan risiko menderita penyakit degeneratif pada usia dewasa janin yang sedang dikandung. (Mutalzimah, 2007)

Status gizi ibu sebelum dan selama hamil dapat mempengaruhi pertumbuhan janin yang sedang dikandung bila status gizi ibu normal pada masa sebelum dan selama hamil kemungkinan besar akan melahirkan bayi yang sehat, cukup bulan dengan berat badan normal (Lubis, 2007). Perbaikan keadaan gizi penting untuk meningkatkan kesehatan ibu hamil, menurunkan angka kematian bayi dan balita, meningkatkan kemampuan tumbuh kembang fisik, mental dan sosial anak. Oleh karena itu keadaan gizi merupakan salah satu ukuran penting dari kualitas sumber daya manusia. (Kristijono, 2007)

Berdasarkan latar belakang diatas maka penulis tertarik ingin melakukan penelitian tentang Gambaran status gizi ibu hamil yang melahirkan bayi dengan BBLR Puskesmas Cigalontang Kabupaten Tasikmalaya tahun 2014.

Tujuan dari penelitian adalah mengetahui Gambaran status gizi ibu hamil yang melahirkan bayi dengan BBLR Puskesmas Cigalontang Kabupaten Tasikmalaya tahun 2014.

\section{Metode}

Jenis Penelitian yang digunakan adalah kuantitatif dengan metode deskriptif. Populasi untuk kelompok kasus pada penelitian ini adalah Bayi yang berat badannya rendah (BBLR) dan memiliki data lengkap dalam buku register

yaitu sejumlah 76 bayi. Tehnik 
pengambilan sampel adalah total sampling.

Instrumen dalam penelitian adalah buku register Puskesmas Cigalontang.

Tehnik pengolahan data adalah :

Rancangan Pengolahan Data

1. Pemeriksaan Data (Editing Data)

Dalam hal ini peneliti memeriksa hasil observasi apakah masih ada poin yang kurang jelas. Apabila ada jawaban yang kurang konsisten atau ada poin yang tidak diisi, maka jawaban tersebut dianggap batal(missing)

2. Pemeriksaan Kode (Coding Data)
Melakukan pengkodean data agar tidak terjadi kekeliruan dalam melakukan tabulasi data.

3. Penyusunan Data (Tabulating Data )

Melakukan pengolahan berdasarkan hasil observasi.

4. Memasukan Data (Entry Data)

Tahap terakhir adalah memasukan datadata tersebut kedalam komputer.

Analisis Data

Analisis univariat dilakukan untuk mendeskripsikan variabel status gizi .

\section{Hasil Penelitian}

Berdasarkan hasil penelitian didapatkan hasil sebagai berikut :

\begin{tabular}{|l|l|c|c|}
\hline No & \multicolumn{1}{|c|}{ Status Gizi } & F & \% \\
\hline 1. & Gizi kurang & 68 & 89,4 \\
\hline 2. & Gizi cukup & 8 & 10,6 \\
\hline & Jumlah & 76 & 100 \\
\hline
\end{tabular}

Berdasarkan hasil penelitian didapatkan bahwa mayoritas ibu hamil yang memiliki bayi BBLR adalah gizi kurang $(89,4 \%)$

\section{E. Pembahasan}

Berdasarkan hasil penelitian didapatkan bahwa mayoritas ibu hamil yang memiliki bayi BBLR adalah gizi kurang $(89,4 \%)$. Hal ini sesuai dengan teori perbaikan keadaan gizi penting untuk meningkatkan kesehatan ibu hamil, menurunkan angka kematian bayi dan balita, meningkatkan kemampuan tumbuh kembang fisik, mental dan sosial anak. Oleh karena itu keadaan gizi merupakan salah satu ukuran penting dari kualitas sumber daya manusia hal ini sesuai dengan teori Kristijono tahun 2007.

Hal ini diketahui bahwa kenaikan berat badan ibu selama kehamilan memberikan kontribusi yang sangat penting bagi proses dan output persalinan. Peningkatan berat badan yang adekuat akan memperkecil terjadinya resiko terjadinya persalinan small gestational age (SGA) atau preterm.Kebutuhan peningkatan berat badan untuk setiap wanita berbedabeda. Faktor yang mempengaruhi besarnya kebutuhan berat badan ditentukan oleh tinggi badan dan berat badan, apakah wanita tersebut memiliki berat badan normal, kurang atau lebih sebelum kehamilan.

Berat badan ibu hamil harus memadai karena hal tersebut menentukan berat badan bayi saat lahir dengan kenaikan yang sesuai pada umur kehamilannya. Bisa dikatan berat badan yang ideal ialah berat badan tubuh yang memiliki proporsi seimbang dengan tinggi badan. Gizi kurang bisa menyebabkan berat badan bayi saat lahir juga kurang Hal ini sesuai dengan teori supriasa tahun 2007.

Pertimbangan berat badan merupakan parameter yang paling baik karena menentukan berat badan bayi saat lahir dan menentukan kesehatannya serta memberikan gambaran status gizi dan juga gambaran pertumbuhan, karena 
saat penilaian berat badan dan status gizi ibu hamil sudah mudah terlihat maka akan menentukan berat badan bayi saat lahir, yaitu saat berat badan atau gizi ibu yang kurang akan menyebabkan berat badan bayi yang kurang juga, begitupun sebaliknya status gizi ibu yang baik akan melahirkan bayi yang berat badannya normal.

\section{F. Simpulan dan saran}

Simpulan dari penelitian didapatkan bahwa mayoritas ibu hamil yang memiliki bayi BBLR adalah gizi kurang $(89,4 \%)$

Rekomendasi saran adalah untuk calon ibu hamil persiapan menghadapi kehamilan salah satunya adalah status gizi pada ibu. Dimana gizi ibu akan menentukan keadan gizi bayinya. Ibu hamil memerlukan nutrisi yang cukup dalam menjaga kebutuhan ibu dan janinnya. Bagi ibu hamil dengan gizi kurang memerlukan upaya pemantauan status gizi secara berkala serta mendapatkan bantuan PMT (pemberian makanan tambahan)

\section{G. Referensi}

Emma. (2010). Status Gizi ibu Hamil serta Pengaruhnya Terhadap Bayi Yang Dilahirkan. Availabel from URL :http://emmapinkz.blogspot.c om/2010/11/status-gizi-ibuhamil-serta-pengaruhnya.html. Diakses Maret 2014.

Erni (2010). Dampak Masalah pada BBLR (Bayi Berat Lahir Rendah). Availabel from :http://mulandari.wordpress.c om/2010/12/03/bayi-berat- lahir-rendah- bblr/. Diakses Maret 2014.

Fantiawati, Ika. (2010). Bayi Dengan BBLR. Penerbit Nuha Offset. Yogyakarta.Judarwanto, Widodo. (2011). Penanganan Bayi BBLR . Availabel from :http://bidanlia.blogspot.com/20 11/07/penanganan-bayi-

bblr.html. Diakses Maret 2014.

Kuliah Bidan, (2008). Bayi Berat Lahir Rendah. Availabel from

:http://kuliahbidan.wordpress. com/2008/07/16/bayi-beratlahir-rendah-bblr/. Diakses Maret 2014.

Lusa. (2010) Pengaruh Status Gizi Bagi Ibu Hamil. Availabel from

:http://www.lusa.web.id/peng aruh-status-gizi-bagi-ibuhamil/. Diakses Maret 2014.

Narto, (2011). Merawat Bayi dengan Berat Lahir Rendah (BBLR). Availabel from : http://artikelterbaru.com/keseha tan/kesehatanmasyarakat/merawat-bayidengan-berat-lahir-rendah-bblr20111318.html. Diakses Maret 2014

Restu, Kevin (2010). Cara Penilaian Status Gizi. Availabel from : http://kevinrestu.blogspot.com/ 2010/11/idk-5-cara-penilaianstatus-gizi.html Rosita, N. Ayu (2011). Asuhan Neonatus Bayi dan Balita. Tasikmalaya. 